\title{
AUDIT DELAY, UKURAN KANTOR AKUNTAN PUBLIK, FINANCIAL DISTRES, OPINI AUDIT, DAN UKURAN PERUSAHAAN KLIEN TERHADAP AUDITOR SWITCHING
}

\author{
TAHNIATUN NAILI", NORA HILMIA PRIMASARI \\ Fakultas Ekonomi dan Bisnis Universitas Budi Luhur ${ }^{1,2}$ \\ *Email: tahniatunnaili92@gmail.com
}

\begin{abstract}
This research is conducted to analyze the influence of audit delay, size of public accountant firm, financial distress, audit opinion and company size of auditor switching. The population in this research is used secondary data from the financial statment of all companies listed in the Indonesia Stock Exchange in 2015-2017 as many 529 companies. This research used purposive sampling method and obtained 359 companies' sample. The data analysis used logistic regression analysis with program SPSS version 20. The result of this research show that size of public accountant firm and audit opinion have negative effect on auditor switching. While audit delay, financial distress and company size have no effect on auditor switching.
\end{abstract}

Keywords: Auditor switching; audit delay; size of public accountant firm; financial distress; audit opinion; company size

\section{PENDAHULUAN}

Perusahaan yang sudah melakukan Initial Public of Offerating atau perusahaan yang Go Public wajib mempublikasikan laporan keuangan yang telah di audit oleh pihak independen setiap tahunnya (Wea dan Murdiawati, 2015). Menurut PSAK 1 (2018) Laporan keuangan adalah suatu penyajian terstruktur dari posisi keuangan dan kinerja keuangan. Tujuan laporan keuangan untuk menyediakan informasi menyangkut posisi keuangan, kinerja serta posisi keuangan suatu entitas yang bermanfaat bagi sejumlah besar pengguna pengambilan keputusan ekonomi. Laporan keuangan tersebut dapat dijadikan sebagai tolak ukur atas dasar keputusan bagi pihak manajemen dalam menjalankan aktivitas perusahaan dimasa yang akan datang. Selain itu laporan keuangan juga digunakan oleh pihak luar seperti investor untuk menjadikan bahan pertimbangan dalam berinvestasi di perusahaan tersebut. Untuk menyakinkan laporan keuangan berisi informasi yang akurat, relevan dan dapat dipertanggung jawabkan dalam mempresentasikan keadaan perusahaan yang sebenarnya, laporan keuangan harus diaudit oleh auditor eksternal atau auditor independen. Auditor independen yang dimaksud adalah auditor yang berasal dari Kantor Akuntan 
Jurnal Ilmiah Akuntansi Universitas Pamulang - Vol. 8, No. 1, Januari 2020 - Naili \& Primasari

Publik (KAP), yang memberikan kewajaran atas penyajian laporan keuangan yang sesuai dengan prinsip-prinsip akuntansi yang berlaku.

Indepedensi auditor merupakan kunci seorang auditor untuk menilai kewajaran atas laporan keuangan yang diperiksa. Tetapi, keterkaitan perusahaan dengan suatu kantor akuntan publik dalam waktu yang lama dapat mempengaruhi indepedensi auditor tersebut sehingga memungkinkan adanya hubungan tertentu antara kantor akuntan publik dengan perusahaan yang diaudit. Adanya hubungan tersebut, dapat menimbulkan kerjasama apabila ada penyimpangan yang dilakukan oleh perusahaan. Untuk mencegah terjadinya hal tersebut pemerintah telah menetapkan peraturan bahwa perusahaan wajib mengganti auditornya atau melakukan auditor switching sesuai dengan batas waktu yang di tetapkan yang diatur dalam Peraturan Pemerintah Republik Indonesia Nomor 20 Tahun 2015 tentang "Praktik Akuntan Publik". Meskipun terdapat peraturan mengenai batas waktu pergantian auditor, pada kenyataan ada perusahaan yang melakukan auditor switching di luar dari peraturan tersebut. Apabila perusahaan dalam jangka waktu lama tidak melakukan auditor switching maka akan membuat hubungan perusahaan dan kantor akuntan publik semakin dekat dan mengancam indepedensi kantor akuntan publik tersebut. Namun, apabila perusahaan terlalu sering melakukan auditor switching akan meningkatkan biaya audit perusahaan tersebut dan menandakan bahwa kantor akuntan publik tersebut tidak profesional.

Fenomena auditor switching yang terjadi di Indonesia pada perusahaan yang terdaftar di Bursa Efek Indonesia (BEI) tahun 2015-2017. Dari 359 Perusahaan yang terdaftar di Bursa Efek Indonesia 4 (empat) perusahaan yang melakukan pergantian kantor akuntan publik atau auditor switching yaitu, PT Cakra Mineral Tbk, PT Ekadharma Internatioal Tbk, PT Langgeng Makmur Tbk dan PT Bank Yudha Bhakti Tbk. Perusahaan-perusahaan ini melakukan auditor switching secara berturut-turut pada tahun 2015-2017. Berdasarkan fenomena tersebut, menimbulkan pertanyaan mengenai faktor-faktor yang mempengaruhi terjadinya auditor switching. Penelitian ini bermaksud untuk menguji secara empiris faktor-faktor yang mempengaruhi auditor switching. Variabel yang digunakan penelitian ini adalah audit delay, ukuran kantor akuntan publik, financial distress, opini audit dan ukuran perusahaan klien. Alasan faktor-faktor tersebut dijadkan sebagai variabel independen adalah membuktikan eksistensi hasil penelitian sebelumnya.

\section{LANDASAN TEORI}

\section{Teori Keagenan}

Menurut Jesen dan Meckling (1976) dalam Sukadana dan Wirakusuma (2016) Hubungan keagenan adalah pendelegasian wewenang yang dilakukan oleh pemilik entitas (principal) kepada manajemen (agent) yang didalamnya terdapat pengembalian keputusan untuk melakukan sejumlah pekerjaan tertentu atas nama principal terkait dalam suatu kontrak kerjasama yang legal. Agent merupakan pihak yang menerima wewenang untuk mengelola perusahaan dan principal merupakan pihak yang membuat kontrak. Masalah keagenan timbul dikarenakan, 
Jurnal Ilmiah Akuntansi Universitas Pamulang - Vol. 8, No. 1, Januari 2020 - Naili \& Primasari

orang yang cenderung untuk mementingkan dirinya sendiri dan juga ketika beberapa kepentingan bertemu dalam suatu aktfitas bersama. Baik agent maupun principal menginginkan keuntungan sebesar-besarnya serta terhindar dari risiko yang kemungkinan terjadi di dalam perusahaan. Teori keagenan menimbulkan adanya asimetri informasi antar agent dan principal. Agent yang mempunyai informasi lebih mengenai kondisi perusahaan dibandingkan principal, hal tersebut dapat berpotensi terjadinya auditor switching dikarenakan agent menginginkan kinerja perusahaan baik untuk memenuhi keinginan principal.

\section{Auditor Switching}

Auditor switching merupakan perpindahan Akuntan Publik dan Kantor Akuntan Publik yang dilakukan oleh perusahaan karena adanya rotasi auditor maupun Kantor Akuntan Publik (Soraya dan Harindi, 2017). Auditor switching dapat bersifat mandatory (wajib) atau voluntary (sukarela). Auditor switching yang bersifat mandatory (wajib) terjadi karena melaksanakan kewajiban dari ketentuan regulasi yang berlaku.

Di Indonesia, pergantian auditor secara mandatory auditor switching (wajib) telah diatur dalam Peraturan Pemerintah Republik Indonesia Nomor 20 Tahun 2015 tentang "Praktik Akuntan Publik". Dalam pasal 11 ayat 1 sampai 3 dijelaskan bahwa pemberian jasa audit atas informasi keuangan historis terhadap suatu entitas oleh seorang akuntan publik dibatasi paling lama untuk 5 (lima) tahun buku berturut-turut. Akuntan publik dapat memberikan kembali jasa audit terhadap suatu entitas setelah 2 (dua) tahun buku berturut-turut tidak memberikan jasa audit di entitas tersebut. Untuk memperketat pengawasan terhadap Akuntan Publik (AP), Otoritas Jasa Keuangan (OJK) mengeluarkan Peraturan Nomor 13/POJK.03/2017 tentang "Pengguna Jasa Akuntan Publik dan Kantor Akuntan Publik dalam Kegiatan Jasa Keuangan". Dalam pasal 16 ayat 1 sampai 3 dijelaskan tentang pihak yang melaksanakan kegiatan jasa keuangan wajib membatasi pengguna jasa audit atas informasi keuangan historis tahunan dari AP yang sama paling lama 3 (tiga) tahun buku berturut-turut. Sementara itu, pembatasan pengguna jasa dari KAP tergantung pada hasil evaluasi komite audit terhadap potensi risiko atas pengguna jasa dari KAP yang sama secara berturutturut untuk kurun waktu yang cukup panjang. Pihak yang melakukan jasa keuangan hanya dapat menggunakan kembali jasa audit atas informasi keuangan historis tahunan dari akuntan publik yang sama setelah 2 (dua) tahun buku pelaporan secara berturut-turut tidak menggunakan jasa audit atas informasi keuangan historis tahunan dari akuntan publik yang sama.

\section{Audit Delay}

Audit delay didefinisikan sebagai jumlah hari tanggal tutup buku tahun perusahaan 31 Desember sampai tanggal di tanda tanganinya laporan audit (Pawitri dan Yadyana, 2015). Audit delay yang tepat waktu akan bermanfaat bagi pengambilan keputusan yang dilakukan pengguna laporan keuangan dan mengurangi asimetris informasi. Audit delay yang terlalu lama akan menurunkan relevansi dari informasi laporan keuangan sehingga mempengaruhi keputusan yang diambil oleh pemegang saham, karena investor beranggapan keterlambatan 
Jurnal Ilmiah Akuntansi Universitas Pamulang - Vol. 8, No. 1, Januari 2020 - Naili \& Primasari

pelaporan keuangan merupakan pertanda buruk kondisi suatu perusahaan. Hal ini didukung dengan penelitian Pawitri dan Yadyana (2015) yang membuktikan bahwa audit delay berpengaruh positif terhadap auditor switching.

\section{$\mathrm{H}_{1}$ : Audit delay berpengaruh positif terhadap auditor switching}

\section{Ukuran Kantor Akuntan Publik}

Ukuran KAP ukuran yang menentukan besar kecilnya suatu Kantor Akuntan Publik (KAP), dibedakan menjadi dua kelompok yaitu KAP yang berafiliasi dengan KAP Big 4 dan KAP yang tidak berafiliasi dengan KAP Big 4 (Wea dan Murdiawati, 2015). KAP big 4 dianggap mampu mempertahankan tingkat indepedensi yang memadai dari pada KAP non big 4, karena biasanya menyediakan layanan untuk klien dalam jumlah besar, sehingga mengurangi ketergantungan mereka pada klien tersebut. KAP big 4 dapat meningkatkan kepercayaan perusahaan untuk investasi diperusahaan tersebut. Sehingga perusahaan yang menggunakan KAP big 4 akan mempertahannya KAP nya dan memiliki kemungkinan kecil melakukan auditor switching. Hal ini di dukung oleh hasil penelitian Aprianti dan Hartanty (2016) yang membuktikan bahwa ukuran kantor akuntan publik berpengaruh negatif terhadap auditor switching.

$\mathrm{H}_{2}$ : Ukuran kantor akuntan publik berpengaruh negatif terhadap auditor switching

\section{Financial Distress}

Financial distress merupakan kondisi tidak sehat ataupun kesulitan keuangan sehingga dikwatirkan perusahaan akan mengalami kebangkrutan, tingkat rasio DAR yang aman adalah 50\%, jika tingkat rasio diatas 50\% maka terjadi satu indikator memburuknya kinerja keuangan dan perusahaan akan mengalami financial distress (Faradila dan Yahya, 2016). Financial distress keadaan di mana perusahaan mengalami kesulitan keuangan sehingga di khawatirkan akan mengalami kebangkrutan. Perusahaan yang mengalami financial distress tidak dapat memenuhi kewajiban finansial perusahaan dan sulit dalam memenuhi biaya audit yang di bebankan oleh kantor akutan publik. Keadaan financial distress suatu perusahaan akan cenderung melakukan auditor switching sesuai dengan kemampuan financial perusahaan dalam mengelurkan biaya audit. Hal ini di dukung oleh hasil penelitian Khasharmeh (2015) yang menyatakan bahwa financial distress berpengaruh positif terhadap auditor switching.

\section{$\mathrm{H}_{3}$ : Financial distress berperngaruh positif terhadap auditor switching}

\section{Opini Audit}

Opini audit merupakan suatu pernyataan opini atau pendapat dari auditor atas suatu laporan keuangan perusahanaan, setelah auditor melakukan pemeriksaan atas kewajaran suatu laporan keuangan perusahaan (Pawitri dan Yadyana, 2015). Financial distress keadaan di mana perusahaan mengalami kesulitan keuangan sehingga di khawatirkan akan mengalami kebangkrutan. Perusahaan yang mengalami financial distress tidak dapat memenuhi kewajiban financial perusahaan dan sulit dalam memenuhi biaya audit yang di bebankan oleh

* Corresponding author's e-mail: tahniatunnaili92@gmail.com http://openjournal.unpam.ac.id/index.php/JIA 
Jurnal Ilmiah Akuntansi Universitas Pamulang - Vol. 8, No. 1, Januari 2020 - Naili \& Primasari

kantor akuntan publik. Keadaan financial distress suatu perusahaan akan cenderung melakukan auditor switching sesuai dengan kemampuan finansial perusahaan dalam mengelurkan biaya audit. Hal ini di dukung oleh hasil penelitian Khasharmeh (2015) yang menyatakan bahwa financial distress berpengaruh positif terhadap auditor switching.

\section{$\mathrm{H}_{3}$ : Financial distress berpengaruh positif terhadap auditor switching}

\section{Ukuran Perusahaan Klien}

Ukuran Perusahaan merupakan skala yang dapat diukur dengan total aset yang dimiliki perusahaan, yang menenunjukkan bahwa perusahaan tersebut semakin besar atau sebaliknya (Wea dan Murdiawati, 2015). Ukuran perusahaan suatu perusahaan semakin besar akan sulit memantau tindakan yang dilakukan manajemen sehingga memerlukan kantor akuntan publik yang tingkat indepedensi yang tinggi dan sesuai dengan ukuran perusahaan tersebut. Ukuran perusahaan yang besar cenderung untuk mempertahankan kantor akuntan publik dan kecenderungan perusahaan melakukan auditor switching semakin kecil. Hal ini didukung oleh penelitian Wea dan Murdiawati (2015) yang membuktikan bahwa ukuran perusahaan klien berpengaruh negatif terhadap auditor switching.

$\mathrm{H}_{5}$ : Ukuran perusahaan klien berpengaruh negatif terhadap auditor switching

\section{METODOLOGI PENELITIAN}

\section{Teknik Pengumpulan Data}

Penelitian ini menggunakan data sekunder yaitu laporan tahunan yang sudah diaudit (annual report) yang terdaftar di Bursa Efek Indonesia (BEI). Penelitian ini menggunakan data sekunder dengan teknik pengumpulan data dari dokumen yang telah didapatkan. Untuk mendapatkan data yang dibutuhkan, cara yang dilakukan adalah sebagai berikut :

1. Riset Lapangan (Field Research)

Penelitian ini menggunakan data sekunder yang didapat dari website resmi Bursa Efek Indonesia (BEI) yaitu www.idx.co.id. Data yang diambil adalah laporan tahunan yang telah diaudit oleh auditor independen pada tahun 20142017.

2. Riset Kepustakaan

Penelitian ini menggunakan data-data yang bersumber dari buku-buku, jurnaljurnal hasil penelitian, internet dan sumber lain yang relevan dengan objek penelitian.

3. Evaluasi dari Pengumpulan Data

Dari data yang diperoleh terdapat 529 perusahaan yang digunakan dalam penelitian, tetapi hanya 359 perusahaan yang masuk dalam kriteria sampel penelitian 
Jurnal Ilmiah Akuntansi Universitas Pamulang - Vol. 8, No. 1, Januari 2020 - Naili \& Primasari

\section{Operasionalisasi Variabel}

Tabel 3.1

Operasional Variabel

\begin{tabular}{|c|c|c|c|c|}
\hline No & Variabel & Indokator & Skala & Sumber Data \\
\hline 1. & $\begin{array}{l}\text { Auditor Switching (Y : } \\
\text { Soraya dan Harindi (2017) }\end{array}$ & $\begin{array}{l}1=\text { Melakukan auditor } \\
\text { switching } \\
0=\text { tidak melakukan } \\
\text { auditor switching }\end{array}$ & Nominal & $\begin{array}{l}\text { Laporan } \\
\text { Keuangan }\end{array}$ \\
\hline 2. & $\begin{array}{l}\text { Audit Delay }\left(\mathrm{X}_{1}\right) \text { : Pawitri } \\
\text { dan Yadnyana }(2015)\end{array}$ & $\begin{array}{lr}\text { Audit Delay }= & \text { Tanggal } \\
\text { Laporan } & \text { Auditor } \\
\text { Independen }- & \text { Tanggal } \\
\text { Tutup Buku } & \end{array}$ & Rasio & $\begin{array}{l}\text { Laporan } \\
\text { Keuangan }\end{array}$ \\
\hline 3. & $\begin{array}{l}\text { Ukuran Kantor Akuntan } \\
\text { Publik }\left(\mathrm{X}_{2}\right) \text { : Wea dan } \\
\text { Murdiawati }(2015)\end{array}$ & $\begin{array}{l}1=\text { Kantor akuntan } \\
\text { publik big } 4 \\
0=\text { Kantor akuntan } \\
\text { publik non big } 4\end{array}$ & Nominal & $\begin{array}{l}\text { Laporan } \\
\text { Keuangan }\end{array}$ \\
\hline 4. & $\begin{array}{l}\text { Financial Distress }\left(\mathrm{X}_{3}\right) \text { : } \\
\text { Faradila dan Yahya }(2016)\end{array}$ & $\begin{array}{l}\text { DAR }= \\
\text { Total Hutang } \\
\text { Total Aset }\end{array}$ & Rasio & $\begin{array}{l}\text { Laporan } \\
\text { Keuangan }\end{array}$ \\
\hline 5. & $\begin{array}{l}\text { Opini Audit }\left(\mathrm{X}_{4}\right) \text { : Pawitri } \\
\text { dan Yadnyana }(2015)\end{array}$ & $\begin{array}{l}1=\text { Wajar tanpa } \\
\text { pengecualian } \\
0=\text { Selaian wajar tanpa } \\
\text { pengecualian }\end{array}$ & Nominal & $\begin{array}{l}\text { Laporan } \\
\text { Keuangan }\end{array}$ \\
\hline 6. & $\begin{array}{l}\text { Ukurann Perusahaan }\left(\mathrm{X}_{5}\right) \text { : } \\
\text { Pratiwi dan Muliartha } \\
(2019)\end{array}$ & $\begin{array}{l}\text { Ukuran Perusahaan = } \\
\text { Ln (Total Aset) }\end{array}$ & Rasio & $\begin{array}{l}\text { Laporan } \\
\text { Keuangan }\end{array}$ \\
\hline
\end{tabular}

\section{Populasi dan Sampel}

Dalam penelitian ini, populasi yang digunakan adalah seluruh perusahaan yang terdaftar di Bursa Efek Indonesia pada tahun 2015-2017 dengan tahun pengamatan mulai dari tahun 2014-2017 sebanyak 529 perusahaan. Alasan pemilihan populasi ini karena seluruh perusahaan terdaftar di Bursa Efek Indonesia (BEI) mempublikasikan laporan keuangannya yang telah diaudit oleh audit independen. Dalam laporan audit independen tersebut dapat mengetahui terjadinya auditor switching. Sedangkan alasan penulis memilih periode 20152017 adalah karena peraturan terkait Peraturan Pemerintah Republik Indonesia Nomor 20 Tahun 2015 tentang "Praktik Akuntan Publik". Dalam pasal 11 ayat 1 sampai 3 dijelaskan bahwa pemberian jasa audit atas informasi keuangan historis terhadap suatu entitas oleh kantor akuntan publik dibatasi paling lama untuk 5 (lima) tahun buku bertrut-turut. Tetapi beberapa perusahaan yang terdaftar di Bursa Efek Indonesia (BEI) tahun 2015-2017 melakukan pergantian Kantor Akuntan Publik (KAP) secara sukarela atau bukan karena peraturan pemerintah yang ditetapkan. Maka dari itu, seluruh perusahaan yang terdaftar di bursa efek indonesia menarik untuk diteliti.

Dalam penelitian ini menggunakan nonprobability sampling, yaitu purposive sampling. Dalam Sugiyono (2017), menyatakan bahwa purposive sampling adalah teknik penentuan sampel yang memerlukan pertimbangan tertentu dalam kreteria yang ditetapkan. Adapun kreteria yang ditetapkan untuk pengambilan sampel pada penelitian ini adalah sebagai berikut: 
Jurnal Ilmiah Akuntansi Universitas Pamulang - Vol. 8, No. 1, Januari 2020 - Naili \& Primasari

1. Seluruh sektor perusahaan yang terdaftar di Bursa Efek Indonesia (BEI) pada tahun 2014-2017.

2. Seluruh sektor perusahaan yang menerbitkan laporan keuangan beserta laporan auditor independen secara lengkap pada akhir tahun buku 31 Desember selama periode 2014-2017.

3. Perusahaan yang melakukan Initial Public Offering (IPO) di Bursa Efek Indonesia sebelum tahun 2014.

Seluruh sektor perusahaan yang menggunakan mata uang Rupiah untuk mata uang pelaporan selama periode 2014-2017. Ketentuan ini dilakukan karena salah satu variabel independen dalam penelitian ini diukur dengan menggunakan Ln total aset, nilai tersebut merupakan akumulasi dari aset yang dimiliki perusahaan secara keseluruhan. Sehingga apabila nilai total aset dikonversikan menggunakan kurs pada tanggal tertentu dikwatirkan akan menimbulkan risiko fluktuasi nilai tukar mata uang.

\section{Teknik Analisis Data}

Untuk menganalisis data yang diperoleh, teknik analisis data dalam penelitian ini menggunakan program IBM SPSS Statistics 20. Teknik analisis data yang digunakan adalah regresi logistik. Pengujian regresi logistik dilakukan dengan beberapa tahap, yaitu: ststistik deskriptif dan analisis regresi logistik.

\section{HASIL PENELITIAN DAN PEMBAHASAN}

\section{Data Analysis}

Populasi dalam penelitian ini adalah seluruh perusahaan go public yang terdaftar di Bursa Efek Indonesia dan data di peroleh dari website resmi Bursa Efek Indonesia yaitu www.idx.co.id. Data yang diperoleh sebayak 1077 data dari 359 perusahaan selama 2015-2017. Berdasarkan uji statisktik deskriptif diperoleh hasil yang nampak pada tabel 4.1, 4.2 dan 4.3. Hasil uji yang tampak pada tabel 4.1 menunjukkan bahwa data tidak mengalami penyimpangan, jrn untuk semua variabel menunjukkan standar deviasi lebih kecil dari rata-rata

Tabel 4.1: Statistik Deskriptif

\begin{tabular}{|c|c|c|c|c|c|}
\hline & $\mathrm{N}$ & Minimum & Maximum & Mean & Std. Deviation \\
\hline $\begin{array}{l}\text { Audit Delay } \\
\text { Financial Distress } \\
\text { Ukuran Perusahaan } \\
\text { Valid N (listwise) }\end{array}$ & $\begin{array}{l}1077 \\
1077 \\
1077 \\
1077\end{array}$ & $\begin{array}{r}7 \\
, 00 \\
22,42\end{array}$ & $\begin{array}{r}353 \\
8,31 \\
34,66\end{array}$ & $\begin{array}{r}76,40 \\
, 5583 \\
28,8110\end{array}$ & $\begin{array}{r}23,360 \\
, 51145 \\
1,87949\end{array}$ \\
\hline
\end{tabular}

Tabel 4.2: Statistik Deskriptif Frekuensi Auditor Switching

\begin{tabular}{|l|l|l|l|l|}
\hline Auditor Switching & \\
\hline & Frequency & Percent & Valid Percent & $\begin{array}{l}\text { Cumulative } \\
\text { Percent }\end{array}$ \\
\hline
\end{tabular}


Jurnal Ilmiah Akuntansi Universitas Pamulang - Vol. 8, No. 1, Januari 2020 - Naili \& Primasari

\begin{tabular}{|ll|r|r|r|r|}
\hline \multirow{2}{*}{ Valid Auditor } & 905 & 84,0 & 84,0 & 84,0 \\
& Switching & & & \\
& & 172 & 16,0 & 16,0 & 100,0 \\
& Auditor Switching \\
$\quad$ Total & 1077 & 100,0 & 100,0 & \\
\hline
\end{tabular}

Sumber : Data diolah sendiri (2019)

Tabel 4.3: Statistik Deskriptif Frekuensi Ukuran Kantor Akuntan Publik

\begin{tabular}{|c|c|c|c|c|c|}
\hline & & Frequency & Percent & Valid Percent & $\begin{array}{l}\text { Cumulative } \\
\text { Percent }\end{array}$ \\
\hline \multirow{3}{*}{ Valid } & Non Big 4 & 686 & 63,7 & 63,7 & 63,7 \\
\hline & Big 4 & 391 & 36,3 & 36,3 & 100,0 \\
\hline & Total & 1077 & 100,0 & 100,0 & \\
\hline
\end{tabular}

Sumber : Data diolah sendiri (2019)

Tabel 4.4: Statistik Deskriptif Frekuensi Opini Audit

\begin{tabular}{|c|c|c|c|c|c|c|}
\hline & & & Frequency & Percent & Valid Percent & $\begin{array}{l}\text { Cumulative } \\
\text { Percent }\end{array}$ \\
\hline \multirow{3}{*}{ Valid } & $\begin{array}{l}\text { Selain Wajar } \\
\text { Pngecualian }\end{array}$ & Tanpa & 311 & 28,9 & 28,9 & 28,9 \\
\hline & $\begin{array}{l}\text { Wajar } \\
\text { Pengecualian }\end{array}$ & Tanpa & 766 & 71,1 & 71,1 & 100,0 \\
\hline & Total & & 1077 & 100,0 & 100,0 & \\
\hline
\end{tabular}

Sumber : Data diolah sendiri (2019)

Pengujian hipotesis dilakukan untuk mengetahui apakah ada pengaruh antara variabel independen dalam penelitian terhadap variabel dependen secara terpisah. Pengujian hipotesis dapat dilihat dari tabel sebagai berikut :

Tabel 4.5: Variables in the Equation

\begin{tabular}{|c|c|c|c|c|c|c|c|}
\hline & & B & S.E. & Wald & df & Sig. & $\operatorname{Exp}(B)$ \\
\hline \multirow{6}{*}{$\mathrm{p} 1^{\mathrm{a}}$} & $\mathrm{AD}$ & ,002 & ,003 & ,315 & 1 &, 574 & 1,002 \\
\hline & UK &,- 743 & ,220 & 11,356 & 1 & ,001 & , 476 \\
\hline & FD &, 130 & 133 & ,947 & 1 & ,330 & 1,139 \\
\hline & $\mathrm{OA}$ &,- 748 & , 180 & 17,284 & 1 & ,000 & ,473 \\
\hline & UP &,- 045 &, 052 & ,744 & 1 & ,388 & ,956 \\
\hline & Constant & ,094 & 1,562 & ,004 & 1 & ,952 & 1,099 \\
\hline
\end{tabular}

a. Variable(s) entered on step 1: AD, UK, FD, OA, UP.

Sumber : Data diolah sendiri (2019)

\section{Hasil Penelitian}

\section{Pengaruh Audit Delay terhadap Auditor Switching}

Hasil penelitian ini menunjukkan bahwa $\mathrm{H}_{1}$ ditolak, yang berarti variabel audit delay tidak memiliki pengaruh terhadap auditor switching. Penelitian ini menunjukkan bahwa cepat atau lama auditor dalam menyelesaikan laporan audit independen tidak menjadikan pertimbangan suatu perusahaan untuk melakukan 
Jurnal Ilmiah Akuntansi Universitas Pamulang - Vol. 8, No. 1, Januari 2020 - Naili \& Primasari

auditor switching. Karena, pada saat perusahaan melakukan auditor switching maka perlu waktu untuk auditor baru dalam mengerti keadaan perusahaan dan menyesuaikan diri dengan lingkungan perusahaan dan tidak menjamin bahwa auditor baru dapat melaksanakan pengauditan lebih cepat dibandingkan dengan auditor lama. Hasil penelitian ini konsisten dengan penelitian Pratiwi dan Muliartha (2019) yang membuktikan bahwa audit delay tidak berpengaruh terhadap auditor switching. Tetapi hasil penelitian ini tidak konsisten dengan penelitian yang dilakukan oleh Soraya dan harindhi (2017) yang membuktikan bahwa audit delay memiliki pengaruh terhadap auditor switching.

\section{Pengaruh Ukuran Kantor Akuntan Publik terhadap Auditor Switching}

Hasil penelitian ini menunjukkan bahwa $\mathrm{H}_{2}$ diterima, yang berarti variabel ukuran kantor akuntan publik memiliki pengaruh signifikan terhadap auditor switching dengan arah pengaruh negatif dapat diartikan jika perusahaan yang telah menggunakan auditor yang berasal dari kantor akuntan publik yang berafiliasi dalam KAP big 4 maka perusahaan tersebut memiliki kemungkinan yang kecil untuk melakukan auditor switching. Kantor akuntan publik yang berafiliasi dalam KAP big 4 adalah kantor akuntan publik yang bereputasi, di mana kantor akuntan publik tersebut dipercaya bahwa menghasilkan kualitas audit laporan keuangan yang baik dan indepedensi auditor yang tinggi. Hasil penelitian ini konsisten dengan penelitian yang dilakukan Arinta dan Adiwibowo (2013) dan Aprianti dan Hartanty (2016) yang membuktikan bahwa kantor akuntan publik berpengaruh negatif terhadap auditor switching. Tetapi hasil penelitian ini tidak konsisten dengan penelitian yang dilakukan oleh Oktavia, Suzan dan Yudowati (2017) dan Fakhri, Majidah dan Nurbaiti (2018) yang membuktikan bahwa ukuran Kantor Akuntan Pubik (KAP) tidak berpengaruh terhadap auditor switching.

\section{Pengaruh Financial Distress terhadap Auditor Switching}

Hasil analisis data menunjukkan bahwa $\mathrm{H}_{3}$ ditolak, yang berarti variabel financial distress tidak memiliki pengaruh terhadap auditor switching. Penelitian ini menunjukkan bahwa keadaan kesulitan keuangan yang dialami perusahaan tidak menjadikan pertimbangan perusahaan untuk melakukan auditor switching. Karena, perusahaan terlalu sering melakukan auditor switching dapat menurunkan kepercayaan dan anggapan negatif dari pemegang saham dan kreditur. Jika perusahaan melakukan auditor switching, auditor yang baru akan memerlukan waktu untuk mengerti keadaan perusahaan dan menyesuaikan diri dengan lingkungan perusahaan serta memahami lingkungan bisnis klien dan risiko audit klien hal ini dapat mengakibatkan keterlambatan dalam penyajian laporan keuangan yang menyebabkan perusahaan menanggung biaya denda keterlambatan dan itu akan menambah beban untuk perusahaan. Perusahaan dalam kondisi financial diatress akan sulit untuk menanggung hal tersebut. Penelitian ini konsisten dengan penelitian yang dilakukan oleh Faradila dan yahya (2016) dan Pratiwi dan Muliartha (2019) yang membuktikan bahwa financial distress tidak berpengaruh terhadap auditor switching. Tetapi hasil penelitian ini tidak konsisten dengan penelitian yang dilakukan oleh Wea dan Murdiawati (2015) dan 
Jurnal Ilmiah Akuntansi Universitas Pamulang - Vol. 8, No. 1, Januari 2020 - Naili \& Primasari

Kasharmeh (2015) yang membuktikan bahwa financial distress memiliki pengaruh terhadap auditor switching.

\section{Pengaruh Opini Audit terhadap Auditor Switching}

Hasil analisis data menunjukkan bahwa $\mathrm{H}_{4}$ diterima, yang berarti variabel opini audit secara parsial memiliki pengaruh terhadap auditor switching. Penelitian ini menunjukkan bahwa opini yang diberikan oleh seorang auditor dapat dijadikan pertimbangan oleh perusahaan untuk melakukan auditor switching. Opini audit memiliki pengaruh negatif terhadap auditor switching yang dapat diartikan apabila perusahaan mendapatkan opini wajar tanpa pengecualian maka perusahan tersebut memutuskan tidak melakukan auditor switching. Opini yang dilakukan auditor menentukan apakah penyajian laporan keuangan wajar dan bebas dari kesalahan. Jika auditor memberikan opini wajar tanpa pengecualian dapat menarik kepercayaan dari pihak luar pengguna laporan keuangan terhadap perusahaan tersebut. Hasil penelitian ini konsisten dengan penelitian oleh Fakhri, Majidah dan Nurbaiti (2018) yang menyatakan bahwa opini audit memiliki pengaruh negatif terhadap auditor switching. Tetapi penelitian tidak konsisten dengan penelitian yang dilakukan Pawitri dan Yadyana (2015).

\section{Pengaruh Ukuran Perusahaan terhadap Auditor Switching}

Hasil penelitian ini menunjukkan bahwa $\mathrm{H}_{5}$ ditolak, yang berarti variabel ukuran perusahaan tidak memiliki pengaruh terhadap auditor switching. Penelitian ini menunjukkan bahwa ukuran dari suatu perusahaan tidak menjadikan pertimbangan untuk melakukan auditor switching. Hasil ini menolak hipotesis yaitu kecenderungan perusahaan besar melakukan auditor switching lebih kecil dibandingkan dengan perusahaan kecil. Perusahaan yang ukurannya besar maupun kecil memilih auditor sesuai dengan ukuran perusahaan tersebut. Karena ketika perusahaan puas dengan kinerja auditor cenderung untuk mempertahankan auditor tersebut. Hasil penelitian ini konsisten dengan penelitian yang dilakukan Fakhri, Majidah dan Nurbaiti (2018) yang membuktikan bahwa ukuran perusahaan tidak berpengaruh terhadap auditor switching. Tetapi hasil penelitian ini tidak konsisten dengan penelitian yang dilakukan oleh Pratiwi dan Muliartha (2019) yang membuktikan bahwa ukuran perusahaan berpengaruh terhadap auditor switching.

\section{KESIMPULAN}

Penelitian ini dilakukan untuk mengetahui pengaruh audit delay, ukuran kantor akuntan publik, financial distress, opini audit dan ukuran perusahaan klien terhadap auditor switching. Hasil analisis dari pengujian hipotesis dalam penelitian ini dapat disimpulkan Ukuran kantor akuntan publik dan opini audit berpengaruh negatif terhadap auditor switching sedangkan audit delay, financial distress dan ukuran perusahaan klien tidak berpengaruh terhadap auditor switching.

Hasil penelitian ini menunjukkan bahwa Kantor akuntan publik yang termasuk dalam big 4 merupakan kantor akuntan publik yang bereputasi, memiliki 
Jurnal Ilmiah Akuntansi Universitas Pamulang - Vol. 8, No. 1, Januari 2020 - Naili \& Primasari

kualitas audit yang baik dan tingkat indepedensi yang tinggi. Perusahaan menginginkan kantor akuntan publik yang berafiliasi big 4 untuk mendapatkan kepercayaan yang tinggi dari investor. Oleh karena itu, perusahaan dapat melakukan auditor switching apabila kantor akuntan publik yang digunakan adalah kantor akuntan publik yang termasuk non big 4. Opini audit dapat diajadikan acuan untuk menilai kewajaran atas laporan keuangan apakah perusahaan telah menerapkan prinsip-prinsip yang sesuai dengan akuntansi yang berlaku serta menentukan kewajaran pernyajian laporan keuangan yang menggambarkan kinerja perusahaan tersebut. Maka dari itu, perusahaan menginginkan opini wajar tanpa pengecualian yang dikeluarkan oleh auditor independen karena dapat menarik kepercayaan investor terhadap perusahaan. Untuk menjaga kepercayaan tersebut, perusahaan akan melakukan auditor switching apabila perusahaan mendapatkan opini selain wajar tanpa pengecualian.

Penelitian selanjutnya diharapkan dapat mempertimbangkan variabel independen lain diluar penelitian ini, dengan menggunakan penelitian ini sebagai acuan untuk melakukan penelitian baru terhadap auditor switching. Variabel independen yang dapat digunakan antara lain; pergantian manajemen, audit fee, kulitas audit, pertumbuhan perusahaan, persentase perubahan ROA dan opini audit going concern. Penelitian selanjutnya diharapkan dapat mempertimbangkan penggunaan model perhitungan lain diluar penelitian ini. Misalnya untuk perhitungan financial distress dapat menggunakan perhitungan model Altman Zscore atau DER (Debt to Equity Ratio).

\section{DAFTAR PUSTAKA}

Aprianti, Siska dan Sri Hartaty. (2016). Pengaruh Ukuran KAP, Ukuran Perusahaan dan Tingkat Pertumbuhan Perusahaan Klien terhadap Auditor Switching. Jurnal Akuntansi Politeknik Sekayu (ACSY). Vol.4 No.1. Hal 45-56.

Arinta, Dara Khasaras dan Santosa Adiwibowo. (2013). Analisis Faktor-Faktor yang Mendorong Pergantian Kantor Akuntan Publik (KAP). Diponegoro Journal of Accounting Vol.2. No.4. Hal 1-11.

Fakhri, Muhammad, Majidah dan Annisa Nurbaiti. (2018). Pengaruh Opini Audit, Ukuran Kantor Akuntan Publik (KAP) dan Ukuran Perusahaan terhadap Auditor Switching. E-Proceeding of Management. Vol.5.No.1. Hal 747752.

Faradila, Yuka dan M. Rizal Yahya. (2016). Pengaruh Opini Audit. Financial Distress dan Pertumbuhan Perusahaan Klien terhadap Auditor Switching. Jurnal Ilmiah Mahasiswa Ekonomi Akuntansi (JIMEKA). Vol.1.No.1. Hal 81-100. 
Jurnal Ilmiah Akuntansi Universitas Pamulang - Vol. 8, No. 1, Januari 2020 - Naili \& Primasari

Khasharmeh, Hussein Ali. (2015). Determinants of Auditor Switching in Bahraint's Listed Companies-an Wmpirical Study. European Journal of Accouting, Auditing and Finance Research. Vol.3.No.11. Hal 73-99.

Pawitri, Ni Made Puspa dan Ketut Yadnyana. (2015). Pengaruh Audit Delay, Opini Audit, Reputasi Auditor dan Pergantian Manajemen pada Voluntary Auditor Switching. E-Jurnal Akuntansi Universitas Udayana. Vol10.1. Hal 214-228.

Pratiwi, I Dewa Ayu Adelia dan Ketut Muliartha. (2019). Pengaruh Financial Distress, Ukuran Perusahaan dan Audit Delay terhadap Pergantian Auditor. E-Jurnal Akuntansi Universitas Udayana. Vol.26.2. Hal 10481074.

Soraya, Ella dan Musfiari Haridhi. (2017). Faktor-faktor yang nenpengaruhi voluntary auditor switching. Jurnal Ilmiah Mahasiswa Ekonomi Akuntansi (JIMEKA). Vol.8.3. Hal 48-62.

Sugiyono. 2017. Metode Penelitian Kuantitatif, Kualitatif dan R\&D. Bandung: Alfabeta

Sukadana, I Dewa Made dan Made Gede Wirakusuma. (2016). Pengaruh Kantor Akuntan Publik Memoderasi Opini Audit Going Concern dan Audit Delay terhadap Auditor Switching. E-Jurnal Akuntansi Universitas Udayana. Vol.16.2. Hal 1604-1634.

Wea, Alexandros Ngala Solo dan Dewi Murdiawati. (2015). Faktor-Faktor yang Mempengaruhi Auditor Switching secara Voluntary pada Perusahaan Manufaktur. Jurnal Bisnis dan Ekonomi. Vol. 22.No. 2. Hal 154-170.

Peraturan Pemerintah Republik Indonesia Nomor: 20 Tahun 2015 Tentang Praktik Akuntan Publik

Peraturan Otoritas Jasa Keuangan Nomor: 29/POJK.04/2016 Tentang Laporan Tahunan Emiten atau Perusahaan Publik

Peraturan Otoritas Jasa Keuangan Nomor 13/POJK.03/2017 Tentang Penggunaan Jasa Akuntan Publik dan Kantor Akuntan Publik dalam Kegiatan Jasa Keungan 